\title{
Production of Chimeric Hepatitis B Virus Surface Antigens in Mammalian Cells
}

\author{
Mihaela-Olivia Dobrica, Catalin Lazar, and Norica Branza-Nichita
}

\begin{abstract}
The small (S) envelope protein of the Hepatitis B Virus (HBV), HBV-S, has the unique ability to selfassemble into highly immunogenic subviral particles (SVPs), in the absence of other viral factors, in eukaryotic cells, including those of nonhepatic origin. This feature is currently exploited for generation of SVPs exposing heterologous epitopes on their surface that can be used as vaccine candidates to target various diseases. Here, we describe a simple and robust method for production of such chimeric HBV-S protein-based SVPs in transiently transfected HEK293T cells and purification from cell supernatants by ultracentrifugation on sucrose cushion and sucrose step gradients. The SVPs obtained by this methodology have been successfully used in immunogenicity studies in animal models.
\end{abstract}

Key words HBV, Antigens, Protein production, Purification, Subviral particles, Vaccine

\section{Introduction}

A variety of expression systems are available for production of protein antigens and vaccine development. The ideal vaccine candidate should be highly immunogenic and suitable for high yield production at low costs. While Escherichia coli is the most costefficient production platform for many soluble proteins, mammalian transmembrane and secretory proteins undergoing complex folding and posttranslational processing are usually not compatible with expression in prokaryotic cells [1]. These transformations, requiring intra- and intermolecular disulfide bonds and specific glycosylation patterns, are often crucial for the biological properties, including protein antigenicity. By providing the appropriate eukaryotic milieu for protein processing as well as scalability, yeast and insect cell cultures have become popular alternative hosts to prokaryotes for high yield expression of many biopharmaceutical

Mihaela-Olivia Dobrica and Catalin Lazar contributed equally to this work. 
proteins. However, the limited capacity of their $\mathrm{N}$-glycosylation pathway to produce only high-mannose oligosaccharides remains an important drawback when expressing proteins that are structurally or functionally dependent on $\mathrm{N}$-linked glycan processing to complex type structures $[2,3]$. In this case, the mammalian cell is the host of choice as it provides all posttranslational modifications of the native protein.

The Hepatitis B Virus (HBV) small (S) surface antigen (HBV-S) is a multispanning transmembrane protein that forms disulfide bridge-stabilized dimers within the endoplasmic reticulum (ER) of the host cells [4]. The dimers spontaneously associate into $20 \mathrm{~nm}$-diameter subviral particles (SVPs) that do not incorporate the viral capsid and genetic material and are secreted from cells, independent of virions (Fig.1) [5]. These virus-like particles (VLPs) are highly immunogenic, non-infectious and can be produced in large amounts in heterologous expression systems in the absence of any other viral components, which has led to their development into efficient and safe vaccines against HBV [6]. These remarkable properties of the HBV-S protein have been exploited to generate chimeric SVPs carrying foreign and HBV-derived epitopes either fused or co-expressed with HBV-S [7-11]. Several insertion sites have been tested for their ability to accommodate epitopes of different lengths within the luminal domain of the $S$ proteins, containing the major B-cell epitopes (the "a" determinant), and two have been shown to be compatible with SVP production and secretion. Chimeric HBV-S proteins bearing foreign peptide sequences allowed for VLP formation and secretion and triggered specific humoral and cellular immune responses against the native protein $[7,8]$.

Here we describe a method for mammalian cell production and purification of chimeric HBV particles that combines relevant virus neutralization epitopes of the large (L) and $S$ envelope proteins for further use in immunological investigations. Our previous studies have indicated that the $\mathrm{HBV} \mathrm{S} / \mathrm{preSl}^{21-47}$ chimera obtained by insertion of the 21-47 amino acids sequence of the preS1 domain of the L protein between residues 126 and 127 of the " $a$ " determinant of S (genotype D) preserves the SVPs properties and is secretion competent. Moreover, the chimeric protein is a more efficient immunogen than the HBV-S protein, the major component of the current vaccine $[10,11]$. Our approach employs transient transfection of adherent HEK293T cells with plasmids encoding for HBV $\mathrm{S} / \mathrm{preSl}^{21-47}$ and HBV-S, followed by purification of corresponding SVPs from cell supernatant by ultracentrifugation on sucrose cushion and step gradients. This method is simple and scalable and may be applied to similar chimeric HBV particles displaying relevant immunogenic peptides derived from other pathogens of medical interest. 


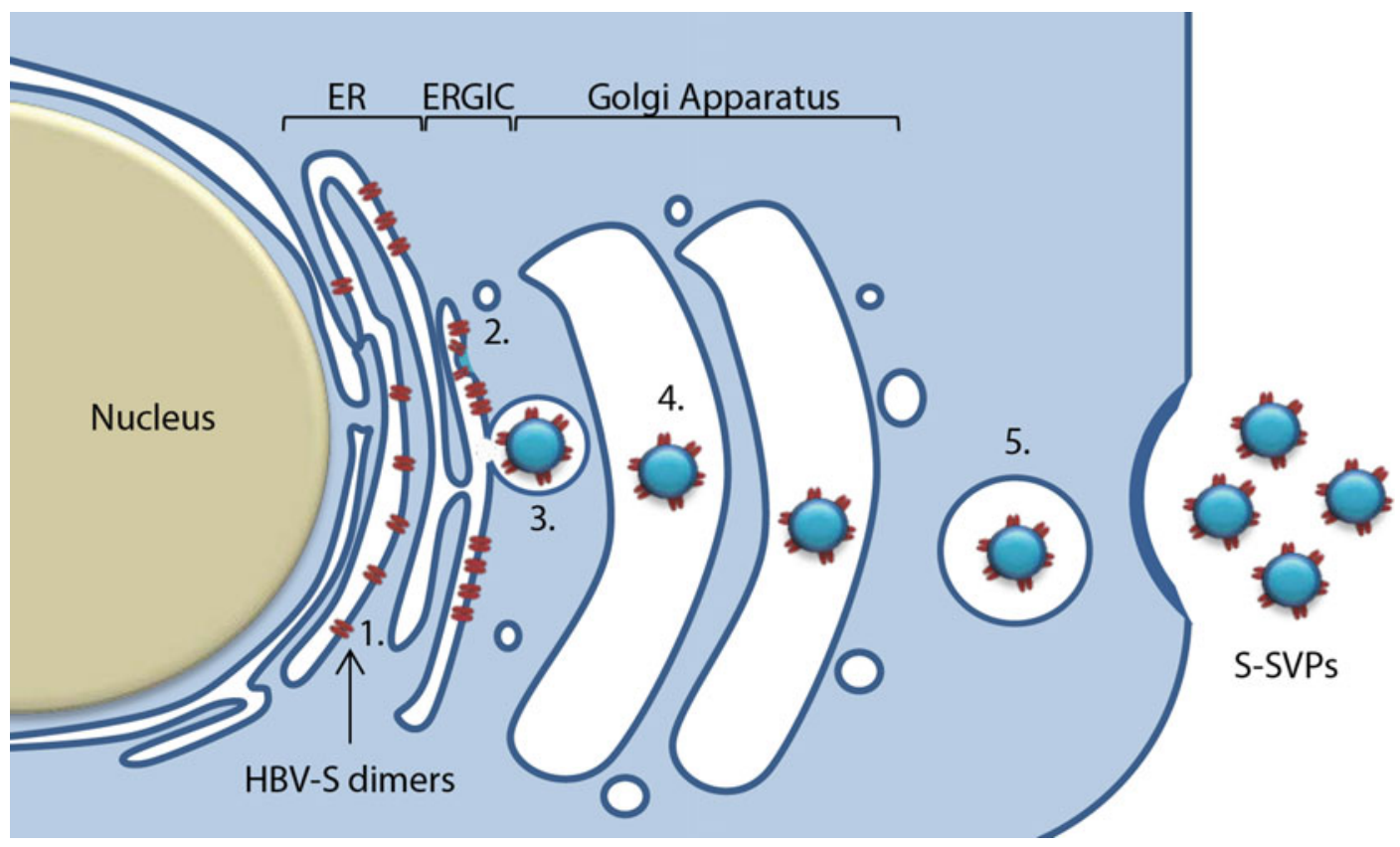

Fig. 1 Assembly of HBV-S subviral particles (S-SVPS). The HBV-S protein is cotranslationally inserted into the ER membrane where it forms disulfide-linked dimers (1) that are further transported to the ER-Golgi intermediate compartment (ERGIC). The dimers associate into higher molecular weight disulfide-linked oligomers that self-assemble with lipids and bud into the ERGIC compartment (2). The resulting $20 \mathrm{~nm}$ particles are sorted into transport vesicles (3), trafficked through the Golgi (4) and exported from cells via the constitutive secretory pathway (5)

\section{Materials}

Prepare all buffers and solutions using deionized water and analytical grade reagents. All cell culture steps are performed in a Biosafety Level 2 laboratory. Manipulation of cells and cell culture reagents is performed in a laminar flow hood using sterile consumables, unless specified otherwise.

\subsection{Cell Culture}

1. HEK293T cells (European Collection of Animal Cell Culture, Porton Down, UK).

2. Dulbecco's Modified Eagle Medium with GlutaMAX ${ }^{\text {TM}_{-}}$I (DMEM, $1 \times$ ). Add $50 \mathrm{~mL}$ fetal bovine serum (see Note $\mathbf{1}$ ) and $5 \mathrm{~mL}$ nonessential amino acids $100 \times$ to a $500 \mathrm{~mL}$ DMEM bottle to obtain complete medium. Store at $4{ }^{\circ} \mathrm{C}$.

3. Cell detaching reagent: $0.05 \%$ trypsin, $0.05 \%$ EDTA in PBS.

4. Cell culture petri dishes $\left(55 \mathrm{~cm}^{2}\right)$ or flasks $\left(75 \mathrm{~cm}^{2}\right)$.

5. Falcon tubes.

6. Disposable serological pipettes.

7. $\mathrm{CO}_{2}$ incubator, set at $37^{\circ} \mathrm{C}$ and $5 \% \mathrm{CO}_{2}$. 


\subsection{Cell Transfection}

\subsection{Detection of Denatured HBV Antigens}

8. Laminar flow hood.

9. For large-scale production: $1700 \mathrm{~cm}^{2}$ ribbed-surface roller bottles and Roll-In $\mathrm{CO}_{2}$ control incubator.

1. Dissolve plasmids pCi-S (encoding for the wild-type HBV-S protein) and $\mathrm{pCi}-\mathrm{S} / \mathrm{preSl}^{2 \mathrm{l}-47}$ (encoding for the chimeric $\mathrm{HBV} S / \mathrm{L}$ protein) in $10 \mathrm{mM}$ Tris- $\mathrm{HCl}, \mathrm{pH} 8.5$ at final concentrations higher than $1 \mu \mathrm{g} \mathrm{DNA} / \mu \mathrm{L}$ (see Note 2 ).

2. Transfection reagent (TR): $1 \mathrm{mg} / \mathrm{mL}$ polyethylenimine (PEI), $\mathrm{pH} 7$.

3. Transfection buffer (TB): Opti-MEM I-GlutaMAX-I.

1. Cell lysis buffer: 0.01 M Tris-HCl, pH 7.5, 0.002 M EDTA, $0.150 \mathrm{M} \mathrm{NaCl}, 0.5 \%$ Triton $\mathrm{X}-100$ and protease inhibitor cocktail $(1 \times)($ see Note 3$)$.

2. Reducing SDS sample loading buffer $(5 \times): 0.25 \mathrm{M}$ Tris- $\mathrm{HCl}$ (pH 6.8), 10\% SDS, $25 \% \beta$-mercaptoethanol, $0.1 \%$ bromophenol blue, $50 \%$ glycerol. Store aliquots at $-20{ }^{\circ} \mathrm{C}$.

3. Nonreducing SDS sample loading buffer $(5 \times)$ : $0.25 \mathrm{M}$ Tris$\mathrm{HCl}$ (pH 6.8), 10\% SDS, $0.1 \%$ bromophenol blue, $50 \%$ glycerol. Store aliquots at $-20{ }^{\circ} \mathrm{C}$.

4. SDS $10 \%$ polyacrylamide (PAA) gels.

5. SDS-PAA gel electrophoresis (SDS-PAGE) running buffer: $0.025 \mathrm{M}$ Tris-HCl, $\mathrm{pH} 8.2,0.190 \mathrm{M}$ glycine, $0.1 \%$ SDS.

6. Peptide: N-glycosidase F (PNG-ase F) and Endoglycosidase $\mathrm{H}$ (Endo H) (see Note 4).

7. Nitrocellulose membrane.

8. Western-blot semidry transfer buffer: $0.025 \mathrm{M}$ Tris- $\mathrm{HCl}$, $0.192 \mathrm{M}$ glycine, $20 \%$ methanol.

9. Phosphate buffer saline (PBS; $10 \times$ ): $1.4 \mathrm{M} \mathrm{NaCl}, 0.027 \mathrm{M}$ $\mathrm{KCl}, 0.1 \mathrm{M} \mathrm{Na}_{2} \mathrm{HPO}_{4}, 0.018 \mathrm{M} \mathrm{KH}_{2} \mathrm{PO}_{4}, \mathrm{pH} 7.4$.

10. Western-blot blocking solution: $10 \%$ nonfat milk in PBS $(1 \times)$.

11. Western-blot washing solution: $0.1 \%$ Tween in PBS $(1 \times)$.

12. Primary mouse anti-preS 1 antibody, secondary anti-mouseHRP antibody.

13. Antibody dilution solution: $1 \%$ nonfat milk, $0.1 \%$ Tween in PBS $(1 \times)$.

14. Enhanced Chemiluminescence detection kit.

15. Purified HBV-L protein for the standard curve.

16. BCA protein assay kit.

17. Prestained molecular weight standards.

18. Autoradiography films. 
19. Refrigerated centrifuge.

20. Mini PROTEAN Tetra system.

21. Semidry transblot system.

22. Heater.

2.4 Detection of Native HBV Antigens

\subsection{Antigen Purification}

1. ELISA-Monolisa HBsAg ULTRA kit (Bio-Rad) ( see Note 5).

2. Multichannel pipette.

3. 96-well plate absorbance reader.

1. Sucrose solutions: $15 \%, 20 \%, 25 \%, 35 \%, 45 \%$, and $60 \%$ sucrose in water. All solutions are heat-sterilized and stored at $4{ }^{\circ} \mathrm{C}($ see Note 6).

2. Ultracentrifuge (SW32Ti and SW41Ti rotors).

3. Ultracentrifuge tubes.

4. Vortex.

5. Dialysis membranes, 10 MWCO.

6. Liquid nitrogen.

7. Lyophilizer.

\section{Methods}

\subsection{Small-Scale HBV Antigen Expression}

Perform all steps at room temperature, unless otherwise indicated.

1. Seed $5 \times 10^{5}$ HEK293T cells in 6 -well plates; add $2 \mathrm{~mL}$ of complete DMEM and grow in a $\mathrm{CO}_{2}$ incubator for $24 \mathrm{~h}$.

2. Replace cell media with $2 \mathrm{~mL}$ of fresh DMEM and transfect cells with either $\mathrm{pCi}-\mathrm{S}$ or $\mathrm{pCi}-\mathrm{S} / \mathrm{preSl}^{21-47}$ plasmids, using a mixture of $200 \mu \mathrm{L} \mathrm{TB}, 6 \mu \mathrm{L}$ TR, and $2 \mu \mathrm{g}$ plasmid DNA per well (see Note 7). Keep nontransfected HEK293T cells as a control (see Note 8).

1. Harvest the HEK293T cells and supernatants at $48 \mathrm{~h}$ posttransfection.

2. Briefly collect cells by centrifugation at $1200 \times g$ for 2 min then incubate resulting pellets with lysis buffer, for $30 \mathrm{~min}$, on ice.

3. Clarify lysates by centrifugation at $10,000 \times \mathfrak{g}$, for $10 \mathrm{~min}$, at $4{ }^{\circ} \mathrm{C}$. Determine the total protein concentration using the $\mathrm{BCA}$ kit, as indicated by the supplier.

4. To monitor the N-glycosylation status of HBV proteins, treat samples either with PNG-ase F or EndoH enzymes, following the protocol provided by the supplier (see Note 9).

5. Heat-denature sample volumes (equivalent of $30 \mu \mathrm{g}$ of total protein/lane) and molecular standards (equivalent of $2 \mu \mathrm{g}$ protein/lane) in the presence of either nonreducing or reducing SDS sample loading buffer, at $95{ }^{\circ} \mathrm{C}$, for $5 \mathrm{~min}$ (see Note 10). 

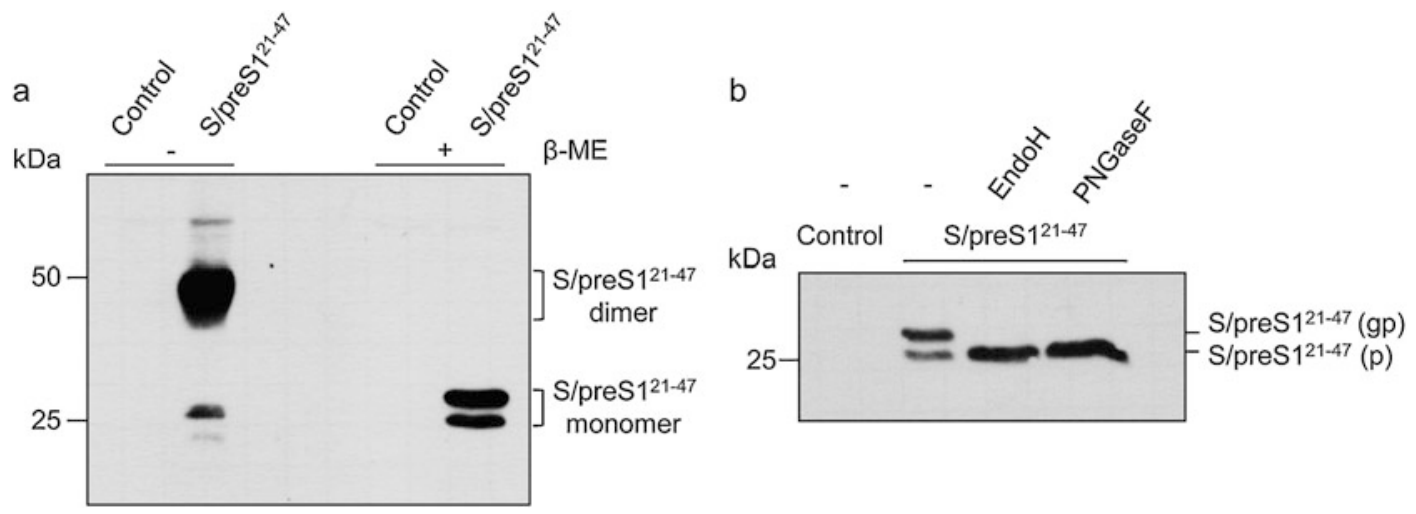

Fig. 2 Expression, oligomerization, and N-glycosylation of the HBV-S/preS $1{ }^{21-47}$ chimeric antigen in HEK293T cells. Lysates of pCi-HBV-S/preS1 ${ }^{21-47}$ - or mock-transfected (control) HEK293T cells were subjected to SDS-PAGE in the presence $(+)$ or absence $(-)$ of $\beta$-mercaptoethanol ( $\beta$-ME) (a). The gels show the migration pattern of antigen monomers and dimers. Cell lysates were also treated with either PNGase $\mathrm{F}$ or Endo $\mathrm{H}$ prior to SDS-PAGE (b). Proteins were detected by western blot using anti-preS1 antibodies. The de-glycosylated (p) and glycosylated (gp) forms of the HBV antigen are shown

6. Load samples on SDS-10\% PAA gels and electrophorese at $30 \mathrm{~mA}$ until the blue dye front reaches the bottom of the gel.

7. Wet nitrocellulose membranes in western-blot transfer buffer and transfer proteins from gels using a semidry blotter, for $75 \mathrm{~min}$ at $60 \mathrm{~mA}$.

8. Block the membranes with $10 \%$ nonfat milk in PBS for $1 \mathrm{~h}$.

9. Incubate membranes with mouse anti-preSl antibody (1/1000 in antibody dilution buffer), for $1 \mathrm{~h}$ ( $\mathrm{see}$ Note 11$)$.

10. Wash the membranes $3 \times$ with western-blot washing solution, 10 min each time.

11. Incubate membrane with anti-mouse-HRP secondary antibody $(1 / 10,000$, in antibody dilution buffer $)$ for $1 \mathrm{~h}$.

12. Incubate membranes with ECL substrate as recommended by the manufacturer and visualize proteins by autoradiography (Fig. 2).

13. Determine secretion of HBV antigens in serially diluted extracellular medium, by using the Monolisa HBsAg ULTRA and the protocol provided by the manufacturer.

14. Quantify the level of secreted $\mathrm{HBV}$ antigens considering the cut-off of the assay $(0.06 \mathrm{ng} / \mathrm{mL})$ and the sample dilution factor (see Note 5 ).

3.3 Large-Scale Cell Culture and Transfection
1. Seed $1 \times 10^{6}$ or $1.5 \times 10^{6}$ HEK293T cells in $55 \mathrm{~cm}^{2}$ Petri dishes or $75 \mathrm{~cm}^{2}$ flasks, respectively. Grow the cells in complete DMEM for 2 days to become 80-90\% confluent.

2. Wash cells with PBS, add trypsin solution to cover the cell monolayer and return to the incubator for $2 \mathrm{~min}$ (see Note 12). 
3. Add $10 \mathrm{~mL}$ DMEM and gently tap the sides of the culture dishes to detach the cells. Pipette cells up and down using a $10 \mathrm{~mL}$ serological pipette, until all clumps are dispersed and a homogenous suspension is obtained.

4. Transfer the cell suspension to Falcon tubes and centrifuge at $1200 \times g$ for $2 \mathrm{~min}$. Remove the supernatant and resuspend the pellet in $10 \mathrm{~mL}$ complete DMEM.

5. Transfer cell suspensions from $5 \times 55 \mathrm{~cm}^{2}$ petri dishes or $4 \times 75 \mathrm{~cm}^{2}$ flasks to $1700 \mathrm{~cm}^{2}$ ribbed-surface roller bottles and add $240 \mathrm{~mL}$ complete DMEM. Grow the cells in a Roll-In $\mathrm{CO}_{2}$ Control Incubator for $72 \mathrm{~h}$.

6. Replace cell media with $200 \mathrm{~mL}$ fresh, complete DMEM. Transfect the HEK293T cells either with pCi-S or pCi-S/ preSl $^{21-47}$ plasmids, using a mixture of $50 \mathrm{~mL} \mathrm{~TB}, 750 \mu \mathrm{L}$ $\mathrm{TR}$, and $500 \mu \mathrm{g}$ plasmid DNA per bottle (see Note 7). Keep a bottle of nontransfected HEK293T cells as control. Return cells to the Roll-In $\mathrm{CO}_{2}$ Control Incubator for $72 \mathrm{~h}$.

7. Collect cell media and clarify by centrifugation at $10,000 \times \mathfrak{g}$, for $10 \mathrm{~min}$, at $4{ }^{\circ} \mathrm{C}$. Store at $4{ }^{\circ} \mathrm{C}$ until further use.

8. Add $200 \mathrm{~mL}$ fresh, complete DMEM to the cells and return the bottles to the incubator for another $72 \mathrm{~h}$ period (see Note 13).

9. Repeat step 3.

10. Harvest cells by flushing up and down $50 \mathrm{~mL}$ PBS using a $10 \mathrm{~mL}$ serological pipette. Centrifuge cell suspensions at $1200 \times g$ for $10 \mathrm{~min}$. Weigh resulting pellets and store at $-20{ }^{\circ} \mathrm{C}$ until further use.

11. Analyze expression and secretion of HBV antigens by ELISA and western blot, as above.

\subsection{Antigen} Purification
1. Pour $4 \mathrm{~mL}$ of $20 \%$ sucrose in $38.5 \mathrm{~mL}$ ultracentrifuge tubes. Gently add $34 \mathrm{~mL}$ media on top of the sucrose cushion. Centrifuge samples at $32,000 \mathrm{rpm}(125,755 \times \mathfrak{g}, \mathrm{SW} 32 \mathrm{Ti}$ rotor $)$ for $5 \mathrm{~h}$, at $4{ }^{\circ} \mathrm{C}$.

2. Carefully remove supernatants by using a serological pipette, leaving about $0.8 \mathrm{~mL}$ of samples at the bottom of the tube. Add $0.2 \mathrm{~mL}$ PBS and leave the tubes overnight on ice (see Note 14).

3. Gently vortex the tube for $10 \mathrm{~s}$ and pool resuspended pellets corresponding to a specific antigen to a final volume of $1.7 \mathrm{~mL}$.

4. Analyze secretion of HBV antigens by ELISA and western blot, as in Subheading 3.2. Include transfected HEK293T cell lysates to compare migration patterns of intra- and extracellular antigens (Fig. 3) ( see Note 15).

5. Pipet $2 \mathrm{~mL}$ of each of $60 \%, 45 \%, 35 \%, 25 \%$, and $15 \%$ sucrose solutions in a $12 \mathrm{~mL}$ ultracentrifuge tube, starting with the higher concentration at the bottom. Gently layer the $1.7 \mathrm{~mL}$ of 


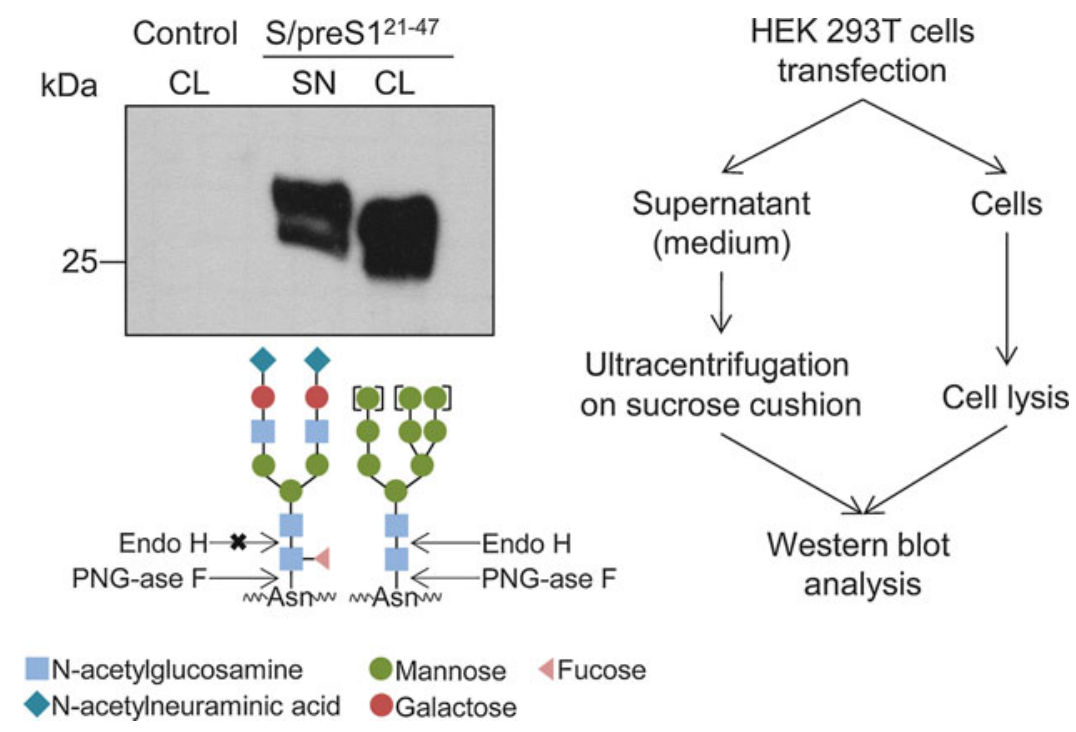

Fig. 3 Secretion of the HBV-S/preS1 ${ }^{21-47}$ chimeric antigen from HEK293T cells. Supernatant of pCi-HBV-S/ preS1 $^{21-47}$-transfected cells were concentrated by ultracentrifugation on a $20 \%$ sucrose cushion and loaded on SDS-PAGE along with corresponding cell lysates (CL), as indicated in the experimental flow chart. Proteins were detected by western blot using anti-preS1 antibodies. Mock-transfected cells were included as control (CL). The diagram below the gel shows a typical composition of complex (left)—and high-mannose N-linked oligosaccharides (right) and the corresponding endoglycosidases cleavage sites. The residues in brackets are usually trimmed in the ER by specific mannosidases

pooled sample on the top of the sucrose gradient using a $5 \mathrm{~mL}$ serological pipette. Centrifuge samples at $30,000 \mathrm{rpm}$ $(111,132 \times g, S W 41$ Ti rotor $)$ for $16 \mathrm{~h}$, at $4{ }^{\circ} \mathrm{C}($ see Note 16$)$.

6. Collect $750 \mu \mathrm{L}$ fractions from the top of the gradient and perform ELISA using the Monolisa HBsAg ULTRA kit.

7. Pool $\mathrm{HBV}$ antigen-positive fractions and dialyze $3 \times$ against $3 \mathrm{~L}$ PBS $0.1 \times$ using SnakeSkin Dialysis Tubing with $10 \mathrm{kDa}$ pores (see Note 17).

8. Freeze-dialyzed samples in liquid $\mathrm{N}_{2}$ and concentrate by lyophilization ( see Note 18).

9. Add sterile water to the protein powder to a final volume of $300 \mu \mathrm{L} /$ antigen $/ 1700 \mathrm{~cm}^{2}$ roller bottle.

10. Quantify HBV antigens levels in the concentrated samples by using Monolisa HBsAg ULTRA kit. Estimate the yields per gram fresh cell weight.

11. Quantify HBV chimeric antigens by western blot using a standard curve made of known amounts of commercial L protein (the preSl antigen, Beacle). A typical example of purified chimeric HBV protein is shown in Fig. 4 (see Note 19).

12. Determine the protein concentration in the concentrated samples by using the BCA protocol and calculate the purity of HBV antigens (see Note 20). 

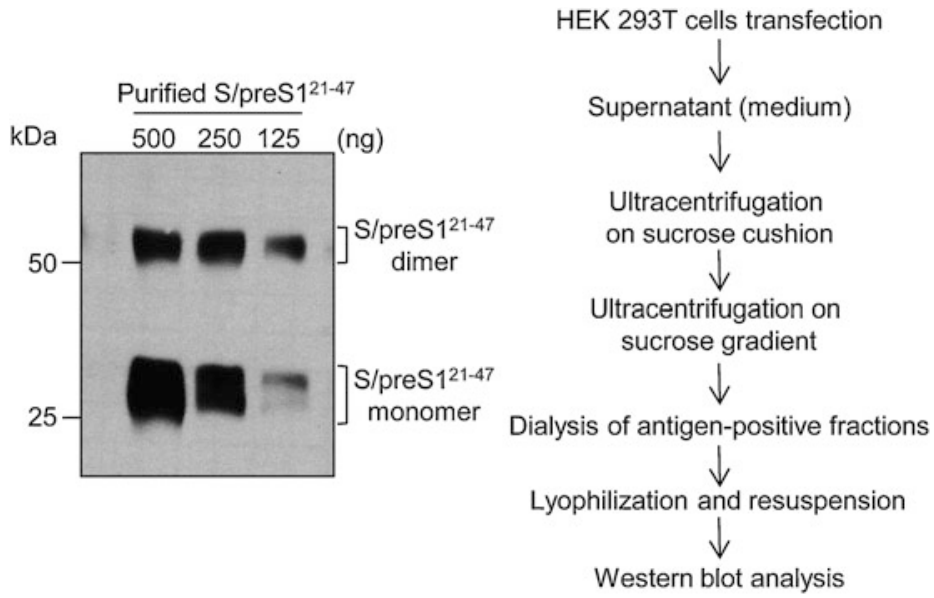

Fig. 4 Quantification of purified HBV-S/preS1 $1^{21-47}$ by western blot. Serial dilutions of the HBV-S/preS1 ${ }^{21-47}$ antigen purified from HEK293T supernatant were loaded on SDS-PAGE followed by western blot and detection with anti-preS1 antibodies. The bands shown correspond to protein monomers and dimers. The numbers above the panel indicate the amount of antigen/lane, as quantified using a pres1 standard curve and the same detection methodology. The protein purification approach is schematically depicted in the experimental flow chart

\section{Notes}

1. The fetal bovine serum is heat-inactivated at $56^{\circ} \mathrm{C}$ for $30 \mathrm{~min}$, aliquoted in $50 \mathrm{~mL}$ Falcon tubes, and stored at $-20^{\circ} \mathrm{C}$.

2. Higher plasmid DNA concentration is desirable as it results in increased stability of the solution while minimizing the volume used in transfection reactions and hence the amount of salts from the solvent. The DNA quality is also essential for optimal transfection and we note that $\mathrm{OD}_{260} / \mathrm{OD}_{280}$ ratios of 1.8 or higher are suitable. To ensure results reproducibility, prepare large stocks of plasmid DNA and store them at $4{ }^{\circ} \mathrm{C}$ for short term use (weeks) or aliquot and store at $-20{ }^{\circ} \mathrm{C}$. Repeated freeze-thaw cycles should be avoided as it damages the DNA solution.

3. The protease cocktail is dissolved and stored according to instructions provided by the manufacturer. When organic solvents are used, prepare stock solutions at least $100 \times$ concentrated to minimize cell toxicity. Always add the protease cocktail to the cell lysis buffer prior to use.

4. PNG-ase F de-glycosylates $N$-linked glycoproteins, regardless of their oligosaccharides structure. Endo $\mathrm{H}$ removes only high mannose and some hybrid types of the $\mathrm{N}$-linked carbohydrates. Therefore, acquirement of complex glycans by proteins, 
especially in the Golgi, results in resistance to Endo $\mathrm{H}$ digestion. Both PNG-ase $\mathrm{F}$ and Endo $\mathrm{H}$ treatments reduce the apparent molecular weight of the glycoprotein, which will change the migration pattern of the protein on SDS gels (as in Fig. 2b).

5. Detection of the HBV surface antigens and SVPs by the Monolisa HBsAg ULTRA kit (Bio-Rad) is based on the reactivity of a mixture of monoclonal antibodies that are highly dependent on the conformation of the "a" determinant of the $S$ domain. Therefore, chimeric HBV proteins containing insertions of foreign epitopes within this region may be less well recognized and their quantification underestimated. In our laboratory we use western blotting under denaturing conditions and antibodies against linear epitopes (preSl) to complete this analysis.

6. Autoclave sucrose solutions at $100{ }^{\circ} \mathrm{C}$ for $20 \mathrm{~min}$ and store at $4{ }^{\circ} \mathrm{C}$. Higher temperature and increased heat exposure may result in sucrose breakdown and sugar caramelization, which will turn the solution yellow-brown. Filter-sterilization is not an option for concentrated sucrose solutions as filters tend to clog.

7. Split TB in equal volumes and add TR and the plasmid DNA solution to each half, then mix them before cell transfection. This will prevent DNA being precipitated when in contact with concentrated TR.

8. We have also run experiments using HEK293T cells transfected with empty pCi vector as a control and found no difference in reactivity of cellular background proteins against anti-HBV antibodies when compared to nontransfected cells.

9. Samples subjected to PNG-ase F and Endo $\mathrm{H}$ digestions are denatured to increase de-glycosylation efficiency, which sometimes results in precipitation of proteins and signal loss in western blots. This can be prevented by reducing the amount of total proteins in the reaction volume.

10. Comparing samples migrated on SDS-PAGE under nonreducing and reducing conditions will provide a first indication on the ability of the HBV chimeric proteins to form disulfide-linked oligomers, a prerequisite for SVPs assembly (as in Fig. 2a).

11. Current commercial antibodies against HBV-S are conformation dependent; therefore, to detect HBV chimeric antigens by western blot, antibodies against linear epitopes are preferred. Membrane incubation with primary antibodies for $\mathrm{l} \mathrm{h}$ is usually sufficient for good signals in western blot, when using monoclonal anti-preSI antibodies. However, overnight incubation is recommended when the antigen is more diluted in analysed samples. No additional membrane washing is necessary.

12. HEK cells are easily detachable; therefore, any washing steps must be performed with care. Pipet solutions on the flask wall 
rather than the cell monolayer. Check cellular morphology under a microscope and incubate a little longer if cells are still attached or not round-shaped yet.

13. This second incubation step is based on our observation that HEK293T cells still contain an important amount of HBV antigens at $72 \mathrm{~h}$ post-transfection and ensures complete release of assembled SVPs into the cell medium.

14. We have observed in our laboratory that some of the SVP sample always remains in the proximity of the pellet as a fine layer that is lost if the entire sucrose solution is removed. By leaving the tubes to rest overnight with a small volume of sample diluted 1:1 in PBS, the pellet gently self-detaches from the bottom of the tube resulting in a concentrated SVP solution that contains at most $10 \%$ sucrose.

15. Comparing the migration pattern of intra- and extracellular antigens on SDS-PAGE under reducing conditions provides valuable information about protein processing along the secretory pathway. Secreted glycosylated HBV antigens will always migrate slower than their intracellular counterparts due to trimming of the $\mathrm{N}$-linked glycan to complex structures (as in Fig. 3). This process can be further confirmed by digestions with PNGase F and Endo H [10].

16. At this stage the SVP sample contains about $10 \%$ sucrose and can be loaded on top of the first, 15\% sucrose-layer of the sucrose step gradient without additional dilution ( $s e e$ also Note 13).

17. Samples are dialyzed against diluted PBS to avoid concentration of salts in the antigen sample after lyophilization.

18. Lyophilization of the HBV antigens results in a protein powder that dissolves easily in water. However, we have observed a slight loss of antigen recognition by the highly conformationdependent monoclonal antibodies of the Monolisa HBsAg ULTRA kit, suggesting that some epitopes may be denatured during this procedure.

19. Serially dilute a protein containing preSl epitope of known concentration to generate a standard curve (500-20 ng). Proceed as in Subheading 3.2 above, steps 6-11 [10].

20. Typically, this protocol leads to production of $28-30 \mu \mathrm{g} / \mathrm{g}$ and $3.75-4 \mu \mathrm{g} / \mathrm{g}$ cell fresh weight of HBV-S and HBV-S/ preSl $^{21-47}$ SVPs, respectively, of about $10-15 \%$ purity, which is compatible with further analysis of the antigenic properties in animal models $[10,12]$. Due to its simplicity and rapidity, this purification approach is particularly suitable for primary screening of a large number of antigens. It can also be used as a precursory step in more sophisticated purification protocols when production of highly pure SVPs might be required. 
Acknowledgments

The research leading to these results has received funding from the EEA Grants 2014-2021, within the GreenVac and SmartVac Projects, contracts no. 5/2014 and no. 1/2019.

\section{References}

1. Dalton AC, Barton WA (2014) Overexpression of secreted proteins from mammalian cell lines. Protein Sci 23(5):517-525

2. Herscovics A, Orlean P (1993) Glycoprotein biosynthesis in yeast. FASEB J 7(6):540-550

3. Altmann F, Staudacher E, Wilson IB, Marz L (1999) Insect cells as hosts for the expression of recombinant glycoproteins. Glycoconj J 16 (2):109-123

4. Siegler VD, Bruss V (2013) Role of transmembrane domains of hepatitis $B$ virus small surface proteins in subviral-particle biogenesis. J Virol 87(3):1491-1496

5. Gilbert RJ, Beales L, Blond D, Simon MN, Lin BY, Chisari FV, Stuart DI, Rowlands DJ (2005) Hepatitis B small surface antigen particles are octahedral. Proc Natl Acad Sci U S A 102(41):14783-14788

6. Komatsu H (2014) Hepatitis B virus: where do we stand and what is the next step for eradication? World J Gastroenterol 20 (27):8998-9016

7. Lee IH, Kim CH, Ryu WS (1996) Presentation of the hydrophilic domains of hepatitis $\mathrm{C}$ viral E2 envelope glycoprotein on hepatitis B surface antigen particles. J Med Virol 50 (2):145-151

8. Netter HJ, Macnaughton TB, Woo WP, Tindle R, Gowans EJ (2001) Antigenicity and immunogenicity of novel chimeric hepatitis B surface antigen particles with exposed hepatitis $\mathrm{C}$ virus epitopes. J Virol 75(5):2130-2141
9. Patient R, Hourioux C, Vaudin P, Pages JC, Roingeard P (2009) Chimeric hepatitis B and $\mathrm{C}$ viruses envelope proteins can form subviral particles: implications for the design of new vaccine strategies. New Biotechnol 25 (4):226-234

10. Dobrica MO, Lazar C, Paruch L, Skomedal H, Steen H, Haugslien S, Tucureanu C, Caras I, Onu A, Ciulean S, Branzan A, Clarke JL, Stavaru C, Branza-Nichita N (2017) A novel chimeric Hepatitis $\mathrm{B}$ virus $\mathrm{S} / \mathrm{preS} 1$ antigen produced in mammalian and plant cells elicits stronger humoral and cellular immune response than the standard vaccineconstituent, $S$ protein. Antivir Res 144:256-265

11. Dobrica MO, Lazar C, Paruch L, van Eerde A, Clarke JL, Tucureanu C, Caras I, Ciulean S, Onu A, Tofan V, Branzan A, Urban S, Stavaru C, Branza-Nichita N (2018) Oral administration of a chimeric Hepatitis B Virus $\mathrm{S} / \mathrm{preSl}$ antigen produced in lettuce triggers infection neutralizing antibodies in mice. Vaccine 36(38):5789-5795

12. Beaumont E, Roingeard P (2015) Chimeric hepatitis $\mathrm{B}$ virus $(\mathrm{HBV}) /$ hepatitis $\mathrm{C}$ virus (HCV) subviral envelope particles induce efficient anti-HCV antibody production in animals pre-immunized with $\mathrm{HBV}$ vaccine. Vaccine 33 (8):973-976

Open Access This chapter is licensed under the terms of the Creative Commons Attribution 4.0 International License (http://creativecommons.org/licenses/by/4.0/), which permits use, sharing, adaptation, distribution and reproduction in any medium or format, as long as you give appropriate credit to the original author(s) and the source, provide a link to the Creative Commons license and indicate if changes were made.

The images or other third party material in this chapter are included in the chapter's Creative Commons license, unless indicated otherwise in a credit line to the material. If material is not included in the chapter's Creative Commons license and your intended use is not permitted by statutory regulation or exceeds the permitted use, you will need to obtain permission directly from the copyright holder.

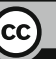

